\title{
Comparison of lateralization thyroplasty and laser cord wedge resection in terms of voice quality in patients with bilateral abductor vocal cord paralysis
}

\section{Bilateral abdüktör vokal kord paralizili hastalarda lateralizasyon tiroplasti ile lazer kord kama rezeksiyonunun postoperatif ses kalitesi açısından karşılaştırılması}

\author{
Dursun Tüzün, ${ }^{1}$ (1) Yusufhan Suoğlu, ${ }^{2}$ (i) Mustafa Sitki Gözeler ${ }^{3}$ \\ ${ }^{1}$ Clinics of ENT, Turhal Government Hospital, Tokat, Turkey \\ ${ }^{2}$ Department of Otorhinolaryngology, Acıbadem Hospital, İstanbul, Turkey \\ ${ }^{3}$ Department of Otorhinolaryngology, Atatürk University Faculty of Medicine, Erzurum, Turkey
}

\begin{abstract}
Introduction: It was aimed to compare lateralization thyroplasty with laser cord wedge resection in terms of postoperative voice analysis, duration of hospital stay, tracheotomy rate, and decannulation time in patients with bilateral abductor vocal cord paralysis. Methods: A total of 37 patients who presented to our department with bilateral abductor vocal cord paralysis between February 2005 and February 2009 were enrolled in this prospective study. External arytenoid lateralization (lateralization thyroplasty) was randomly performed in 22 patients and laser posterior cordotomy was performed in 15 patients. Fifteen healthy volunteers were assigned to the control group. Postoperative $6^{\text {th }}$ month maximum phonation time (MPT), S/Z ratio, and the results of objective voice analysis [mean frequency perturbation (jitter), mean amplitude perturbation (shimmer), mean fundamental frequency (fo), and NHR (noise to harmonic ratio)] were compared between the two groups and the control group. Decannulation time, patient tracheotomy status, and duration of hospital stay were also recorded.

Results: The mean postoperative MPT decreased but S/Z ratio increased in both patient groups compared to the control group. The mean MPT was shorter in the external arytenoid lateralization group versus the laser posterior cordotomy group $(p=0.011)$. There was no statistically significant difference between the external arytenoid lateralization and laser posterior cordotomy groups in terms of mean $S / Z$ ratio $(p=0.306)$. It was observed that jitter, shimmer, and NHR values were increased, i.e. voice quality impaired, in both patient groups. Jitter $(p=0.004)$, shimmer $(p<0.001)$, and NHR $(p=0.052)$ values were significantly increased in the laser posterior cordotomy group as compared with the external arytenoid lateralization group. No statistically significant difference was found between the external arytenoid lat-
\end{abstract}

Özet

Amaç: Bu çalışmada bilateral abdüktör vokal kord paralizili hastalarda lateralizasyon tiroplasti ile lazer kord kama rezeksiyon tekniklerinin postoperatif ses analizi, hastanede kalış süresi, trakeotomi oranı, dekanülasyon zamanı açısından karşılaştııılması amaçlanmıştır.

Gereç ve Yöntem: Kliniğimize şubat 2005 ile şubat 2009 tarihleri arasında bilateral vokal kord paralizisi tanısı ile başvuran 37 hasta bu prospektif çalışmaya dâhil edildi. Rastgele seçilen 22 hastaya eksternal lateralizasyon tiroplasti, 15 hastaya da lazer kordektomi uygulandı. 15 sağlıklı gönüllüden de kontrol grubu oluşturuldu. Postoperatif 6 . ayda iki grup ve kontrol grubunun maksimum fonasyon zamanı (MFZ), S/Z oranı, objektif ses analiz sonuçları [ortalama frekans pertürbasyonu (jitter), ortalama amplitüd pertürbasyonu (shimmer), ortalama temel frekans (fo) ve gürültü-harmonik oranı] değerleri karşılaştırıldı. Ayrıca dekanülasyon zamanı, trakeotomi durumu, hastanede kalış süresi de kaydedildi.

Bulgular: Kontrol grubu ile karşılaştııılığında her iki hasta grubunda ortalama MFZ azalırken, S/Z oranının arttığı izlendi. Ortalama MFZ eksternal lateralizasyon tiroplasti hastalarında lazer kordektomi hastalarına oranla daha kısa idi ( $p=0.011)$. S/Z oranı bakımından iki hasta grubu arasında anlamlı farklılık izlenmedi $(p=0.306)$. Her iki hasta grubunda jitter, shimmer ve gürültü-harmonik oranının arttığı, yani ses kalitesinin bozulduğu görüldü. Lazer kordektomi grubunda eksternal lateralizasyon grubuna göre daha yüksek jitter $(p=0.004)$, shimmer $(p<0.001)$ ve gürültü-harmonik oranı $(p=0.052)$ değerleri tespit edildi. Ortalama fo 
eralization group and the laser posterior cordotomy group in terms of the mean postoperative $f(o)(p=0.417)$, as well as for decannulation time $(p=0.076)$ and duration of hospital stay $(p=2.30)$.

Discussion and Conclusion: External arytenoid lateralization is a more preferable technique than laser posterior cordotomy because it preserves mucosal integrity and cord mass, which results in better voice quality.

Keywords: Jitter; laser cordectomy; lateralization thyroplasty; Shimmer. $(p=0.417)$, dekanülasyon süresi $(p=0.076)$ ve hastanede kalış süreleri $(p=2.30)$ bakımından iki grup arasında anlamlı farklılık yoktu.

Sonuç: Mukoza bütünlüğünü ve kord kitlesini koruması nedeniyle daha iyi ses kalitesine sahip olan eksternal lateralizasyon tiroplasti tekniği, lazer kordektomiden daha tercih edilebilir bir operasyon tekniğidir.

Anahtar Sözcükler: Jitter; lazer kordektomi; lateralizasyon tiroplasti; Shimmer.

The study was based on Dursun Tüzün's specialty thesis under the supervision of Yusufhan Suoğlu.

$A_{i}$ Ithough bilateral abductor vocal cord paralysis (BAVCP) is less common than unilateral vocal cord paralysis, it frequently appears as a life-threatening condition. Respiratory distress of various degrees may occur due to airway obstruction, usually without hoarseness. ${ }^{[1,2]}$

The most common cause of bilateral abductor vocal cord paralysis is iatrogenic. Surgical trauma following thyroidectomy remains the most important cause, followed by other traumas, trachea and esophagus surgeries, malignant diseases, prolonged intubation, and neurologic diseases. ${ }^{[3]}$ Voice quality is minimally influenced by BAVCP because of adequate adduction, which results from innervation of the superior laryngeal nerve. Dyspnea and stridor are the more frequently encountered symptoms. ${ }^{[2]}$ The primary goal of treatment is to preserve swallowing and phonation functions while removing airway obstruction.

Surgical treatment includes selective section of the recurrent laryngeal nerve, ${ }^{[4]}$ bilateral thyroarytenoid muscle myectomy, ${ }_{1}^{[5,6]}$ type II thyroplasty ${ }_{1}^{[7]}$ and laser posterior cordotomy. ${ }^{[8,9]}$ The present study compared postoperative maximum phonation time, $S / Z$ ratio, and the parameters of objective voice analysis (jitter, shimmer, mean fundamental frequency, NHR) between lateralization thyroplasty and laser posterior cordotomy. Patients who underwent one of the surgical interventions were evaluated and compared in terms of preoperative tracheotomy status, postoperative tracheotomy status, decannulation time, and duration of hospital stay.

\section{Materials and Method}

The study was approved by Istanbul University Istanbul School of Medicine Ethics Committee, and written consent with official sign was obtained from the patients. The study comprised 37 patients who presented to Istanbul University Istanbul School of Medicine, Department of Ear Nose and Throat, between February 2005 and February 2009, with bilateral abductor vocal cord paralysis and underwent laser posterior cordotomy or external arytenoid lateralization (lateralization thyroplasty), as well as 15 healthy subjects as the control group. Twenty-two patients were randomized to undergo external arytenoid lateralization and 15 patients underwent endoscopic laser posterior cordotomy.

The sex and age of the patients, disease etiology, presence of tracheotomy before surgery, whether tracheotomy was performed after surgery, day of decannulation, duration of hospital stay, and the results of acoustic analyses performed 6 months after surgery were recorded for all patients. The results were compared between the two surgical groups and with the control group.

Acoustic evaluations were performed in soundproof rooms in the voice laboratory of our clinic. The /a/ sound following a deep inspiration was recorded for each patient. Acoustic analysis consisted of objective measurement of mean fundamental frequency (fo), jitter (\%), shimmer (\%), and noise to harmonic ratio (NHR).

The maximum /a/ sound made by each patient following a deep inspiration and the maximum /s/ and /z/ sounds, again made following a deep inspiration were recorded using a chronometer. The maximum phonation time (MPT) was calculated using the recording of the $/ a /$ sound, and the $S / Z$ ratio was calculated by proportioning the durations of $/ \mathrm{s} /$ and $/ \mathrm{z} /$ sounds.

All patients underwent surgery by the same surgeon. Prednisolone at a dose of $1 \mathrm{mg} / \mathrm{kg}$ was administered, unless contraindicated, to prevent laryngeal edema during surgery. In addition, broad-spectrum prophylactic antibiotics were given for 5 days following surgery. An endoscopic examination was performed during the follow-up period to prevent any likely complications such as laryngeal edema or granulation formation.

\section{Surgical technique \\ External arytenoid lateralization}

If one of the cords is motile, even slightly, on the preoperative indirect laryngoscopy, then the immotile cord was chosen; the atrophic cord was chosen if both cords were immotile. Intubation was performed under general anesthesia using a $5.5-\mathrm{cm}$ intubation tube in the absence of preoperative tracheotomy. $A$ horizontal $10-\mathrm{cm}$ incision was made in line with the skin folds of the neck between the thyroid and cricoid cartilage passing through the skin, subcutaneous tissue, and the platysma muscle. The sternocleidomastoid (SCM) muscle was pulled towards to the lateral aspect. The upper thyroid pole was reached between the SCM muscle, omohyoid, and sternohyoid muscles, and the lateral surface of the thyroid cartilage was exposed. The larynx was turned towards to the opposite side using a hook, the constrictor muscle group was cut through- 
Tablo 1. The mean values of postoperative 6 th-month voice analysis in the patient and control groups

\begin{tabular}{lccr} 
Technique & Arytenoid lateralization $(\mathbf{n}=\mathbf{2 2})$ & LASER Cordotomy $(\mathbf{n}=15)$ & Control $(\mathbf{n}=\mathbf{1 5}$ \\
\hline Postoperative MPT & $2.45(0.92-5.15)$ & $4.57(1.88-12.01)$ & $10.6(5-22)$ \\
Postoperative S/Z & $2.15(0.66-7.9)$ & $1.73(1.04-2.64)$ & $1.33(0.87-1.92)$ \\
Postoperative f(0) & $236(85-480)$ & $208(102-441)$ & $222(192-261)$ \\
Postoperative jitter & $1.12(0.124-2.762)$ & $2.15(0.421-4.723)$ & $0.30(0.13-0.77)$ \\
Postoperative Shimmer & $5.38(0.447-10.1)$ & $9.28(4.205-14.65)$ & $1.96(0.582-5.08)$ \\
Postoperative NHR & $0.29(0.005-0.929)$ & $0.462(0.093-1)$ & $0.013(0.002-0.059)$ \\
\hline
\end{tabular}

Data are presented as mean (minimum-maximum). MPT: Maximum phonation time; $f(0)$ : Fundamental frequency; NHR: Noise to harmonic ratio.

out the thyroid lamina, and the apex of the sinus pyriformis was separated. The cricoarythenoid joint was exposed. The arytenoid cartilage was identified and released from the posterior cricoarytenoid muscle. The inferior horn of the thyroid cartilage was released, and the vocal process of the arytenoid cartilage was found and put on the inferior horn by passing $3 / 0$ round prolene through two different points. The patency of the vocal cords was checked via direct laryngoscopy. Dissimilarly, in the Woodman ${ }^{[10]}$ surgery, the arytenoid body was removed by leaving the vocal process. It is necessary to preserve the laryngeal mucosal integrity to achieve precise blood control (hematoma prevention), and to avoid excessive cauterization for mucosal nutrition, not to impair.

\section{Laser endoscopic posterior cordotomy}

Posterior cordotomy was performed using suspension microlaryngoscopy. For suspension microlaryngoscopy, a Zeiss $16 f$ microscope with a 400-mm lens and a laser laryngoscope were used. A Sharplan 30C laser was used with 14-watt (continuous $0.1 \mathrm{~mm}$ width) power, intermittent cut, and vaporization. A laser-resistant intubation tube was used in patients without preoperative tracheotomy and the area surrounding the vocal cord was protected with wet pads. Injury to the anterior two thirds of the vocal cord and other parts of the laryngeal mucosa was avoided. Laser exposure to the vocal process of the arytenoid cartilage and the internal surface of the thyroid cartilage was also avoided. Posterior cordotomy was performed through the anterior aspect of the arytenoid.

\section{Statistical analysis}

Statistical Package for Social Sciences (SPSS) version 14.0 was used for the statistical analyses. T-test and Chi-square test were used for the comparison of the postoperative $6^{\text {th }}$ month data. The results (given as mean and standard deviation) were evaluated within $95 \%$ confidence intervals and at a significance level of $p<0.05$.

\section{Results}

Of the 22 patients that underwent external arytenoid lateralization, 21 were women, and the mean age was $48.97 \pm 13.1$ years (range, 23-75 years). Of the 15 patients who underwent laser posterior cordotomy, 14 were women, and the mean age was $45.56 \pm 12.32$ years (range, $21-68$ years). The mean age was $31.6 \pm 8.48$ years (range, $21-49$ years) in the control group, which consisted of healthy subjects ( 13 women and 2 men). All patients had bilateral abductor vocal cord paralysis with a duration of paralysis ranging between 3 months and 240 months (mean: 53.27 months). With regard to the etiologic causes, the most common cause was surgical trauma following thyroidectomy $(n=34)$. The cause of paralysis was trauma in one patient and idiopathic in two patients.

Preoperative tracheotomy was present in 6 of the 22 patients who underwent external arytenoid lateralization and in $1 \mathrm{pa}-$ tient who underwent laser posterior cordotomy. Postoperative tracheotomy was not performed in any patients who underwent laser posterior cordotomy, whereas one patient who underwent external arytenoid lateralization required postoperative tracheotomy; the patient was decannulated on day 20. No patients required prophylactic tracheotomy. Patients who underwent external arytenoid lateralization and had preoperative tracheotomy, and the patient who underwent postoperative tracheotomy were decannulated in 1-50 days (mean $6 \pm 14.8$ days). One patient was decannulated late $\left(50^{\text {th }}\right.$ day) because they lived far from the hospital and came late for the follow-up visit. Decannulation time was prolonged ( $45^{\text {th }}$ day) in one patient because they developed a nosocomial infection. The patient who underwent laser posterior cordotomy and had preoperative tracheotomy was decannulated on the $5^{\text {th }}$ day. No statistically significant difference was determined between the two groups in terms of decannulation time because there was one decannulated patient in the laser posterior cordotomy group $(\mathrm{p}=0.076)$.

The patients who underwent external arytenoid lateralization were discharged from hospital in a mean of 5.8 days (range, 1-54 days), and the patients who underwent laser posterior cordotomy were discharged from hospital in a mean of 2.3 days (range, 1-6 days). One patient who underwent external arytenoid lateralization was discharged from the hospital on Day 54 because of a nosocomial infection. No statistically significant difference was determined between the two groups in terms of duration of hospital stay $(p=2.30)$.

All patients who underwent surgery had hoarseness, which was not problematic in daily life. Thirty-seven patients and the control group were compared in terms of postoperative $6^{\text {th }}$ month MPT, S/Z ratio, jitter, shimmer, mean fundamental frequency (fo), and NHR values (Table 1). 
The mean MPT was longer in the control group as compared with the external arytenoid lateralization and laser posterior cordotomy groups $(p<0.001)$. The mean MPT was shorter in the external arytenoid lateralization group as compared with the laser posterior cordotomy group $(p=0.011)$.

There was a significant difference between the control group and external arytenoid lateralization group in terms of postoperative mean $S / Z$ ratio $(p=0.006)$. The difference between the postoperative mean $S / Z$ ratios of the control and the posterior cordotomy group was also statistically significant $(p=0.045)$. There was no statistically significant difference between the external arytenoid lateralization group and the laser posterior cordotomy group in terms of postoperative mean $S / Z$ ratio $(p=0.306)$. It was observed that $S / Z$ was increased in the external arytenoid lateralization group and the laser posterior cordotomy group compared to the control group.

No statistically significant difference was determined between the control group and the external arytenoid lateralization group ( $p=0.555$ ), the control group and the laser posterior cordotomy group $(p=0.593)$, or between the external arytenoid lateralization group and the laser posterior cordotomy group $(p=0.417)$ in terms of mean fundamental frequency $f(o)$.

The mean postoperative frequency perturbation (jitter) value was lower in the control group compared with the external arytenoid lateralization group and the laser posterior cordotomy group ( $p<0.001)$. The mean postoperative jitter of patients in the external arytenoid lateralization group was lower than that of patients in the laser posterior cordotomy group ( $p=0.004)$.

The mean postoperative amplitude perturbation (shimmer) was lower in the control group compared with the external arytenoid lateralization group and laser posterior cordotomy group $(p<0.001)$. The mean postoperative shimmer value of patients in the external arytenoid lateralization group was lower than that of patients in the laser posterior cordotomy group $(p<0.001)$.

The mean NHR was lower in the control group compared with the external arytenoid lateralization group and laser posterior cordotomy group $(p<0.001)$. The difference between the mean postoperative NHR values of the external arytenoid lateralization group and laser posterior cordotomy group was not statistically significant $(p=0.052)$.

Objective voice analysis revealed a postoperative decrease in the duration and quality of voice in both patient groups compared with the control group. Objective voice analysis was better in the external arytenoid lateralization group compared with the laser posterior cordotomy group because mucosal integrity had not been impaired and cord mass was preserved. Although phonation time was better in the laser posterior cordotomy group, voice quality was not. However, there was short-term but more qualitative voice in the external arytenoid lateralization group.

\section{Discussion}

Bilateral vocal cord paralysis (BVCP) is frequently a life-threat- ening condition and a common cause of death due to respiratory distress. It may sometimes be difficult to diagnose because of relatively good voice quality. Patients with BVCP have a narrow airway and inspiratory stridor. It may either be asymptomatic or require intubation or tracheotomy due to respiratory distress that results from edematous vocal cords. [1] Patients generally do not have hoarseness.

Timing for interventions other than tracheotomy remains a matter of debate. The general opinion is to wait for at least 6 months - 1 year after trauma or thyroidectomy for permanent surgical interventions. ${ }^{[1]]}$ Jatko and colleagues followed patients after thyroidectomy and determined permanent paralysis in only $0.5 \% 6$ months after surgery. ${ }^{[12]}$ In the present study, interventions were performed after 6 months at the earliest, and at one year at the latest.

Vocal cord lateralization is the most commonly performed method for the treatment of BVCP. It is performed either externally or endoscopically. Postoperative voice quality is decreased in all interventions performed for vocal cord lateralization. The differences between interventions are related with whether the surgical technique is difficult or easy, intraoperative bleeding is excessive or little, requirement for postoperative tracheotomy, and cosmetic outcomes.

External vocal cord lateralization techniques include total or partial arytenoidectomy, submucosal cordectomy, total ventricle and cord resection, arytenoidopexy, cricoarytenoid arthrodesis, and vocal cord lateralization..$^{[10,13-15]}$

Endoscopic surgeries have come to the fore because of manipulation difficulties, prolonged duration of surgeries, impairment in the larynx skeleton, and prolonged hospital stay encountered with external approaches. Total arytenoidectomy leads to bleeding, risk of aspiration, inadequate phonation, and requirement for postoperative tracheotomy. ${ }^{[16]}$ Whereas cordectomy and ventricle and band resection are good for respiration, the same cannot be claimed for the voice. ${ }^{[16]}$ Different from the Woodman technique ${ }^{[10]}$ arytenoid cartilage is not removed and cord mucosa integrity is not impaired in the external arytenoid lateralization we performed. This approach is convenient, particularly in patients with short necks who are not suitable for the endoscopic approach, and for patients in whom a rigid endoscope could not be placed due to reasons such as micrognathia. Manipulation for the management of bleeding during surgery is easier compared with the endoscopic approach, and vocal cord vibrations are not impaired owing to the preserved mucosal integrity.

Endoscopic vocal cord lateralization techniques include ventriculocordectomy, arytenoidectomy, cord lateralization, laser arytenoidectomy, laser medial arytenoidectomy, laser cordectomy, and laser posterior cordotomy. ${ }^{[17,18]}$ Although respiration is good in ventriculocordectomy and arytenoidectomy, voice quality is not; bleeding may occur and prophylactic tracheotomy may be required. The cord lateralization technique described by Kirschner is an easy method, but it has complications such as broken stitches and stitch-related 
granulation tissue. ${ }^{[19]}$ Laser arytenoidectomy is superior to external arytenoidectomy because it provides better hemostasis, no requirement for tracheotomy, easy surgical technique, safety, minimal invasiveness, and short-duration surgery. ${ }^{[8,9,20]}$ The posterior aspect, which is responsible for respiration, is removed in laser posterior cordotomy, while anterior cord and arytenoid, which are responsible for phonation, are preserved; thus phonation and swallowing functions are less influenced. [21] Laser posterior cordotomy is easier, takes less time, and causes less edema and scarring than external arytenoid lateralization. Dennis and Kashima described posterior cordectomy using a carbon dioxide laser and reported adequate airway and voice quality, which improved within one year. ${ }^{[21]}$

It is expected that MPT would decrease and S/Z ratio, jitter, shimmer, and NHR would increase as a result of impaired voice quality. Maruzzi performed objective voice analysis in the $4^{\text {th }}$ and $10^{\text {th }}$ months after cordotomy together with arytenoidectomy taking MPT, fundamental frequency, and the intensity of sound and reported an acceptable level of impairment in voice quality and intensity. ${ }^{[22]}$ Hans objectively analyzed acoustic and respiratory parameters in the preoperative period and after the postoperative $6^{\text {th }}$ month and demonstrated decreased MPT but increased jitter and shimmer. The authors observed significant improvement in voice quality over the course of 2-year follow-up period. ${ }^{[23]}$ Bakır S. performed endoscopic posterior cordotomy in 26 patients and determined decreased MPT but increased jitter and shimmer in objective voice analysis. ${ }^{[24]}$ In the present study, postoperative $6^{\text {th }}$-month MPT was decreased, but S/Z ratio, jitter, shimmer, and NHR were increased in the 22 patients who underwent external arytenoid lateralization and in 15 patients who underwent laser posterior cordotomy. In the present study, the higher MPT but lower $\mathrm{S} / \mathrm{Z}$ with laser posterior cordotomy as compared with external arytenoid lateralization was attributed to incomplete glottal closure due to the lateralized arytenoid. Jitter, shimmer, and NHR were lower with external arytenoid lateralization as compared with laser posterior cordotomy. This was attributed to the preserved mucosal integrity and vibration function, as well as preserved cord mass and tension with external arytenoid lateralization. The sound was shorter but more qualitative with external arytenoid lateralization.

In the present study, prophylactic tracheotomy was not performed in any patient. Dennis and Kashima published that posterior cordotomy with $\mathrm{CO}_{2}$ laser could be performed without prophylactic tracheotomy. ${ }^{[21]}$ Unsal E. performed the Thornell technique on 19 patients and performed prophylactic tracheotomy in all, and decannulation was performed in a mean of 8.5 days. ${ }^{[25]}$ In the present study, postoperative tracheotomy was required in one (4.5\%) patient who underwent external arytenoid lateralization and the patient was decannulated on the $20^{\text {th }}$ day. No patients who underwent laser posterior cordotomy required postoperative tracheotomy. In total, postoperative tracheotomy was required in one of 37 patients (2.7\%). This was $16.7 \%$ in the study conducted by Dennis and Kashima and $8 \%$ in the study of Laccourreye. ${ }^{[21,26]}$ Tracheotomy requirement was lower in the present study as compared with the literature. Patients who underwent external arytenoid lateralization were decannulated in a mean of 6 days and one patient who underwent laser posterior cordotomy and had preoperative tracheotomy was decannulated on the $5^{\text {th }}$ day. Overall, the patients were decannulated in a mean of 3.7 days. No difference was determined between the two techniques in terms of decannulation days.

Bakır S. performed endoscopic posterior cordotomy and found the mean duration of hospital stay was 7 days. ${ }^{[24]}$ In the present study, the mean duration of hospital stay was 2.33 days in the endoscopic laser posterior cordotomy group and 5.86 days in the external arytenoid lateralization group; overall it was 4.43 days. No difference was determined between the two techniques in terms of duration of hospital stay $(p=2.30)$

\section{Conclusion}

Although laser posterior cordotomy results in longer but poorquality noisy voice, external arytenoid lateralization results in shorter but qualitative voice. Endoscopic laser posterior cordotomy can be performed rapidly and easily, does not require postoperative tracheotomy, and hemostasis can be provided easily; however, external arytenoid lateralization provides better voice quality.

Ethical approval: All procedures performed in studies involving human participants were in accordance with the ethical standards of the institutional and/or national research committee and with the 1964 Helsinki Declaration and its later amendments or comparable ethical standards.

Funding: This research received no specific grant from any funding agency in the public, commercial, or not-for-profit sectors.

Conflict of interest: All authors declare that they have no conflict of interest.

\section{References}

1. Holinger LD, Holinger PC, Holinger PH. Etiology of bilateral vocal cord paralysis. Ann Otol 1976;85;428-36.

2. Kashima HK. Bilateral vocal fold motion impairment. Pathophysiology and management by transverse cordotomy. Ann Otol 1991;100:717-21

3. Tucker HM. Vocal cord paralysis etiology and management Laryngoscope 1980;90:585-90

4. Dedo HH. Recurrent laryngeal nerve section for spastic dysphonia. Ann Otol Rhinol Laryngol. 1976;85:451-459.

5. Nakamura K, Yosida T, Tsukahara K, et al. Clinical feasibility of surgeries for adductor spasmodic dysphonia: complication between thyroarytenoid myectomy and type 2 thyroplasty. J Jpn Bronchoesophogol Soc. 2009;60: 231-239.

6. Su CY, Chuang HC, Tsai SS, Chiu JF. Transoral approach to laser thyroarytenoid myoneurectomy for treatment of adductor spasmodic dysphonia: short-term results. Ann Otol Rhinol Laryngol. 2007;116:11-18.

7. Woodman DG. A modification of the extralaryngeal approach to 
arytenoidectomy for bilateral abductor paralysis. Arch Otolaryngol 1946;43:63-5

8. Ossof RH, Karlan MS, Sisson GA. Endoscopic laser arytenoidectomy. Laser Surg Med 1983;293-9.

9. Ossof Rh, Sisson GA, Duncavage JA. Endoscopic laser arytenoidectomy for the treatment of bilateral vocal cord paralysis. Laryngoscope 1984;94;1293-7.

10. Isshiki N, Tsuji DH, Yamamoto Y, lizuka Y. Midline lateralization thyroplasty for adductor spasmodic dysphonia. Ann Otol Rhinol Laryngol. 2000;109:187-193.

11. Tucker HM: Etiology and management. Laryngoscope 90: 585, 1979

12. Jatko G, Lisborg B, Muller M, Wette V. Recurrent nerve paralysis after thyroid operations. Nerve identification and literature review. Surgery 1994;115: 139-143.

13. Ada M, Öz F, Toprak M, Öktem F, Kaytaz A, Yağız C. CO2 laser arytenoidectomy in laryngeal microsurgery. Turkish ORL Archive. 1999;37:23-6.

14. King BT. A new and functioning respiratory operation for bilateral abductor cord paralysis. JAMA 1939;112:814-23.

15. Kelly JD. Surgical treatment of bilateral paralysis of abductor muscles. Arch Otolaryngol 1941;33:293-304.

16. Eckel HE, Thumfart M, Wasserman K, et al. Cordectomy versus arytenoidectomy in the management of bilateral vocal cord paralysis. Ann Otol Rhinol Laryngol 1994; 103: 852-7

17. Thornell WC. Intralaryngeal approach for arytenoidectomy in bilateral abductor vocal cord paralysis. Arch Otolaryngol 1948;47:505-8.
18. Tucker HM: The larynx. 2. Edition. Thieme medical publishers Inc. New York, 1993.

19. Kirchner F. Endoscopic lateralization of the vocal cord in abductor paralysis of the larynx. Laryngoscope 1979;89:1779-1782.

20. Carbon Dioxide Laser Endoscopic Posterior Cordotomy Technique for Bilateral Abductor Vocal Cord Paralysis JAMA Otolaryngol Head Neck Surg. 2013;139(4):401-404.

21. Dennis DP, Kashima H. Carbon dioxide laser posterior cordectomy for treatment of bilateral vocal cord paralysis. Ann Otol Rhinol Laryngol 1989;96:930-4.

22. Maurizi M, Paludetti G, Galli J, Cosenza A, Di Girolamo S, Ottoviani F. CO2 laser subtotal arytenoidectomy and cordotomy in the treatment of post-thyroidectomy bilateral laryngeal fixation in adduction. Eur Arch Otorhinolaryngol 1999;256:291-5.

23. Hans S, Vaissiere J, Crevier-Buchman L, Laccourreye O, Brasno D. Aerodynamic and acoustic parameters in $\mathrm{CO} 2$ laser posterior transverse cordotomy for bilateral vocal fold paralysis. Acta Otolaryngol 2000;120:330-335

24. Bakır S, Tuncer Ü. In patients with bilateral vocal cord paralysis results of endoscopic posterior Cordotomy. Dicle Med J. 2006;36:178-183.

25. Ünsal E. Öksüzler Ö. Özbek C. Aygenç E. Çelikkanat S. Özdem C. Thornell technique in the treatment of bilateral vocal cord paralysis. Kbbbbc 15(1):7-11, 2007

26. Laccaurreye O, Paz EsCovar MI, Gerhart J, et al. Co2 laser endoscopic posterior partial transverse cordotomy for bilateral paralysis of the vokal fold. Laryngoscope $1999 ; 109 ; 415-8$. 